\title{
KETERTARIKAN MASYARAKAT PEGADUNGAN TERHADAP PENDALAMAN BAKAT BIDANG SENI SEBAGAI AKTIVITAS SEPULANG SEKOLAH
}

\author{
Joshua Christian Chandra ${ }^{1\}}$, Nina Carina ${ }^{2\}}$ \\ 1)Program Studi S1 Arsitektur, Fakultas Teknik, Universitas Tarumanagara, joshuaocu1414@gmail.com \\ 2)Program Studi S1 Arsitektur, Fakultas Teknik, Universitas Tarumanagara, nincarin@gmail.com
}

\begin{abstract}
Abstrak
Kelurahan Pegadungan adalah kelurahan dengan zonasi perumahan. Sebagai suatu kawasan perumahan, kelurahan ini memiliki fasilitas pendidikan (sekolah) yang cukup banyak. Namun untuk dapat bertumbuh dan berkembang, diperlukan fasilitas lain seperti pendalaman bakat pada bidang tertentu yang dapat di kunjungi seusai jam sekolah agar aktivitas anak di luar jam sekolah dapat terwadahi dengan positif. Pada saat ini pendalaman bakat dan ketrampilan pada suatu bidang baik dalam akademis maupun non-akademis menjadi salah satu faktor penting dalam perkembangan anak. Selain itu, Sebagian penduduk merupakan orang-orang dengan profesi sebagai pedagang juga karyawan yang membutuhkan tempat untuk rehat sejenak dari dunia perkantoran. Melalui metode kuisioner dan teori dari buku "The Rise Of The Creative Class, Revisited" by Richard Florida diketahui bahwa Kelurahan Pegadungan membutuhkan tempat untuk refreshing dan pendalaman bakat pada bidang kesenian juga pengembangan UKM. Sehingga dengan adanya Project Third Place Architecture dengan mengangkat aktivitas pendalaman bakat pada suatu bidang diharapkan dapat menjadi wadah yang menghasilkan produk-produk kreatif dari penduduk di Kelurahan Pegadungan.
\end{abstract}

\section{Kata kunci: After School Life; Aktivitas; Kreatif; Pengembangan Bakat; Refreshing}

\begin{abstract}
Pegadungan area, West Jakarta is a housing settlement. As a residential area, this area has several educational facilities (schools). But to be able to grow and develop, other facilities are needed such as the development of talent in certain fields that can be visited after school hours. Thus the activities of children after school can be contained positively. At this time the deepening of talent and skills in an academic and non-academic field is one of the important factors in children's development. Besides, Pegadungan Village also has people who are professionals as traders and employees. Where most of the offices in Jakarta are located in the center of the city that has very heavy traffic, the people who work as employees also need a place to take a break from the office world. Through questionnaire methods and theories from the book "The Rise of the Creative Class, Revisited" by Richard Florida, it is known that Pegadungan Village needs a place for refreshing and deepening talent in the arts as well as the development of SMEs. So that with the Project Architecture as The Third place with Development of Interest Activity is expected to be a container that produces creative products from people in Pegadungan Village.
\end{abstract}

Keywords: After school Activity; After School life; Creative; Development of interest; Refreshing 


\section{PENDAHULUAN}

\section{Latar Belakang}

Kelurahan Pegadungan merupakan kelurahan dengan jumlah penduduk kurang lebih 80.000 jiwa dengan mayoritas zonasi berwarna kuning atau perumahan. Rutinitas sehari-hari yang dilakukan oleh penduduk di Kelurahan ini adalah bekerja untuk orang dewasa dan bersekolah untuk anak-anak. Namun, pada kelurahan ini sangat sedikit didapatkan tempat hiburan untuk refreshing dari rutinitas sehari-hari. Nyatanya dengan refreshing dapat menjernihkan pikiran seseorang dan dapat memaksimalkan kerja seseorang.

Pada kelurahan Pegadungan terdapat 15 sekolah, namun belum ditemukan wadah untuk anak usia sekolah mengerjakan tugas selain di rumah atau di tempat bimbingan belajar dan juga belum adanya wadah untuk anak mengembangkan minat dan bakatnya. Dalam buku "The Rise of The Creative Class" dan "Happy City" banyak aspek-aspek pendukung dimana belajar bisa menjadi menyenangkan seperti diberikan tempat yang unik, hingga menambah nuansa alam pada tempat belajar juga dengan mencampuri hal yang disukai oleh seseorang dapat menambah wawasan dan produktivitas seseorang. Berita Mendikbud baru-baru ini juga mendukung bahwa sekolah kedepannya anak-anak dapat memilih hanya beberapa bidang pelajaran di sekolah yang ia minati. Oleh karena itu, dengan adanya pendalaman minat dan bakat di Kelurahan Pegadungan dapat membuat masyarakat, khususnya usia produktif melakukan aktivitas postif di sela waktu kosong.

\section{Rumusan Masalah}

a. Dalam bentuk apa fasilitas atau program yang berfungsi untuk meningkatkan kemampuan bidang seni warga pada umumnya dan pelajar pada khususnya?

b. Bagaimana wujud fasilitas yang paling sesuai dengan kebutuhan warga secara umum?

c. Wujud arsitektur seperti apa yang dapat diterima oleh lingkungan baik secara fisik maupun non- fisik?

\section{Tujuan}

a. Menyediakan wadah aktivitas pelajar sepulang sekolah yang berfokus pada pendalaman minat dan bakat di bidang seni.

b. Menyediakan ruang interaksi untuk masyarakat kawasan Pegadungan.

c. Menciptakan pusat aktivitas masyarakat yang positif.

d. Memfokuskan anak-anak usia produktif untuk dapat mendalami suatu minat dan bakat pada bidang tertentu.

\section{KAJIAN LITERATUR}

\section{"The Great Good Place" by Ray Oldenburg}

Oldenburg (1997) dalam bukunya "The Great Good Place" menjelaskan Third Place (The core settings of informal public life) adalah tempat public yang didesain agar orang dapat datang dengan sukarela sebagai masyarakat pada umumnya, tidak formal dan dapat merasa bahagia di luar ranah tempat tinggal dan tempat bekerja. Ketiga tempat ini (Tripods) memiliki bagian masing-masing dalam kepentingan masyarakat dan lingkungan, ketiganya saling mendukung.

\section{On Neutral Ground}

Sebuah Kota memiliki keberagaman penduduk dari segi etnis social budaya dan lainnya. Keberagaman ini menjadi sebuah potensi untuk mempelajari perbedaan satu sama lain. Maka dari itu dibutuhkan tempat netral dimana orang dapat datang dan pergi tanpa tujuan dan tanpa ada yang mengklaim bahwa tempat itu adalah tempatnya dan sehingga dapat terasa nyaman untuk setiap orang yang mendatanginya. 
The Third Place Is a Leveler

Sebuah tempat yang dapat didatangi siapa saja (Inclusive). Dan dijadikan tempat untuk berkumpul bertemu orang baru tanpa memandang pangkat atau derajat seseorang.

Conversation Is the Main Activity

Sebuah tempat dapat hidaup dan memberikan kenyaman pada seseorang jika terdapat aktivitas didalamnya. Tidak ada aktivitas yang dapat dilakukan tanpa adanya interaksi sehingga interaksi penting untuk tempat ini. Selain itu interaksi juga dapat di jadikan proses untuk saling intoleran.

\section{Accessibility and Accomodation}

Tempat yang akan dikunjungi ini haruslah merupakan tempat yang nyaman dalam artian dapat di akses dengan mudah, aman dan nyaman. Baik pada pagi hari, siang jua malam.

\section{The Regulars}

Tempat ini harus meberikan kenyamanan pada seseorang dan juga memberikan suatu pengalaman yang bukan merupakan suatu yang tidak jelas sehingga orang-orang yang datang dapat kembali datang ke tempa tersebut.

\section{A Low Profile}

Tempat ini juga harus low profile, maksudnya adalah tempat yang tidak mengintimidasi pengunjungnya karena tampilan yang mewah atau highclass yang dapat membuat orang berpikir duakali untuk memasukinya.

\section{The Mood Is Playful}

Karena tempat ini merupakan tempat yang Neutral, Regular, lowprofile maka tempat ini harus bernuansa Playful dimana orang-orang yang datang dapat melakukan sesuatu yang menyenangkan dan tidak bosan berada di dalamnya.

\section{"The Rise Of The Creative Class, Revisited" by Richard Florida}

Pada Buku ini, Richard Florida megatakan bahwa kota-kota telah salah melihat perkembangan jaman. Ahli-ahli ekonomi berkata bahwa ekonomi sebuah kota akan tumbuh apabila kota tersebut memiliki perusahaan-perusahaan besar, nilai investasi yang tinggi, nilai lahan yang tinggi dan lain sebagainya. Ada juga yang mengatakan bahwa kota akan bertumbuh ekonominya apabila kemajuan teknologi juga tinggi. Namun Florida berkata bahwa sebuah kota akan bertumbuh jika didalamnya terdapat orang-orang kreatif. Mengapa Demikian? Teknologi-teknologi baru, perusahaan besar itu semua muncul karena ada orang kreatif di dalamnya. Lalu ia menegaskan bahwa pada dasarnya semua orang itu adalah kreatif. Namun banyak orang tidak menyadarinya. Contohnya saja orang-orang dapat mengatasi sebuah hal dengan cara yang berbeda-beda, itu sudah membuktikan bahwa orang-orang pada dasarnya adalah kreatif.

Lalu jika berbicara pertumbuhan ekonomi sebuah kota, hal tersebut terkait dengan manusia dan tempat. Orang kreatif biasanya memiliki kebiasaan berkumpul atau berdiskusi dengan orang yang memiliki pemikiran yang sama dengan dia, dimana orang tersebut juga pasti merupakan orang kreatif. Ketika orang kreatif berkumpul dengan sesama orang kreatif, akan menciptakan sebuah peluang dan ide-ide baru bermunculan. Richard Florida juga menambahkan bahwa orang-orang yang belum terlihat kreativitasnya, akan terlihat apa bila "dipicu". Kata dipicu ini dapat diartikan dipicu oleh orang-orang kreatif disekitarnya maupun tempat -tempat kreatif yang didatanginya. Sehingga yang dibutuhkan kota adalah tempattempat yang dapat memicu kreativitas seseorang, guna menghasilkan masyarakat yang kreatif. (Florida, 2014) 


\section{"Happy City" by Charles Montgomery}

Montgomery (2013) pada buku "Happy City" menjelaskan tentang "How To be Closer - Testing Proximity", yang menjelaskan kedekatan manusia dan alam dapat berpengaruh terhadap banyak hal juga dapat membuat seseorang merasa lebih tenang dan berpikiran lebih luas. Lalu, bagaimana cara mendekatkan orang, Montgomery mengatakan "To get closer to one another, we need a little more distance and a little more nature." Yang maksudnya adalah kita tidak dapat memaksakan orang untuk bertemu berinteraksi dan menjadi saling kenal, karena terlalu banyak orang yang ditemui seseorang dalam sehari dapat meningkatkan tingkat stress seseorang. Kita hanya membuat sebuah tempat dimana orang-orang bisa datang lalu ditambah sentuhan alami.

\section{Kurikulum Sekolah Masa Mendatang}

Saat ini, kurikulum sekolah kedepannya akan lebih berfokus pada satu atau beberapa bidang tertentu, hal tersebut sudah dikatakan oleh Menteri Pendidikan dan Budaya Indonesia. Jika dilihat diranah internasional, beberapa kurikulum sudah di terapkan di Indonesia sejak lama. Contohnya Kurikulum Cambridge dan International Baccalaureate (IB) merupakan kurikulum berstandar internasional yang sudah diterapkan di beberapa sekolah. Kurikulum ini mengacu pada beberapa bidang pelajaran tertentu dan bertujuan agar siswa dapat mengembangkan rasa percayadiri dalam mengutarakan pendapat, mengembangkan identitas budaya dan mengetahui apa yang harus dipelajari seseorang. (Hadijah, 2018); Halodoc (2020)

\section{Pengaruh Kreativitas Terhadap Edukasi}

Dalam Kamus Besar Bahasa Indonesia (1990: 456), Kreatif merupakan suatu kemampuan untuk dapat menciptakan atau daya cipta, kreativitas tersebut juga dapat bermakna ialah sebagai kreasi terbaru danjuga orisinil yang tercipta, sebab kreativitas merupakan suatu proses mental yang unik untuk dapat menghasilkan sesuatu yang baru, berbeda serta juga orisinil. Kreativitas adalah aktivitas/ kegiatan otak yang teratur komprehensif, imajinatif yang mengarah pada suatu hasil yang orisinil. Sehingga kreativitas dapat mengembangkan potensi diri untuk menciptakan suatu yang baru.

Kita tahu bahwa dalam dunia profesional dibutuhkan sebuah produk yang orisinil yang dapat terus dikembangkan seiring perkembangan jaman. Untuk memacu pemikiran yang orisinil ini, harus mulai dibiasakan dari sejak produktivitas otak masih bekerja maksimal. Jika dilihat dari penelitian, kinerja otak mencapai puncaknya pada usia 16-18 tahun, dimana usia ini merupakan usia anak sekolah. Sehingga sebaiknya anak usia sekolah lebih ditingkatkan lagi segi kreativitasnya. Psychological Science (2015)

Kreativitas seperti halnya otot, harus sering dilatih berulang kali agar bisa bekerja maksimal dan harus didorong keluar dari zona nyaman. Ada beberapa hal yang dapat mempengaruhi kreativitas seseorang. Beberapa diantaranya adalah; 1) Belajar bersama teman (kelompok). Belajar bersama-sama dapat memperluas pengetahuan seseorang karena banyaknya masukan yang didapat. Selain itu juga kognitif seseorang terpacu karena ide-ide yang dikeluarkan oleh orang lain sehingga belajar bersama akan lebih efektif disbandingkan dengan belajar sendiri. 2) Melakukan sesuatu yang disukai. Ketika seseorang menyukai suatu bidang, hal tersebut akan memicu tingkat penasaran seseorang sehingga semua hal yang berkaitan dengan bidang yang sedang disenangi tersebut. Maka pengetahuanpun akan semakin luas. 3) Berjalan. Cara yang satu ini mungkin akan membuat banyak orang bertanya-tanya maksudnya. Pada penelitian yang dilakukan oleh Stanford Research manusia pada umumnya duduk 7-15 jam per- harinya dan hal ini membuat tingkat kejenuhan seseorang meningkat $70 \%$ sehingga dengan berjalan 
dan tidak menetap pada satu tempat dapat mengurangi tingkat jenuh seseorang dan meningkatkan produktivitas pekerjaan. (Campbell, 2017; Kim, 2015)

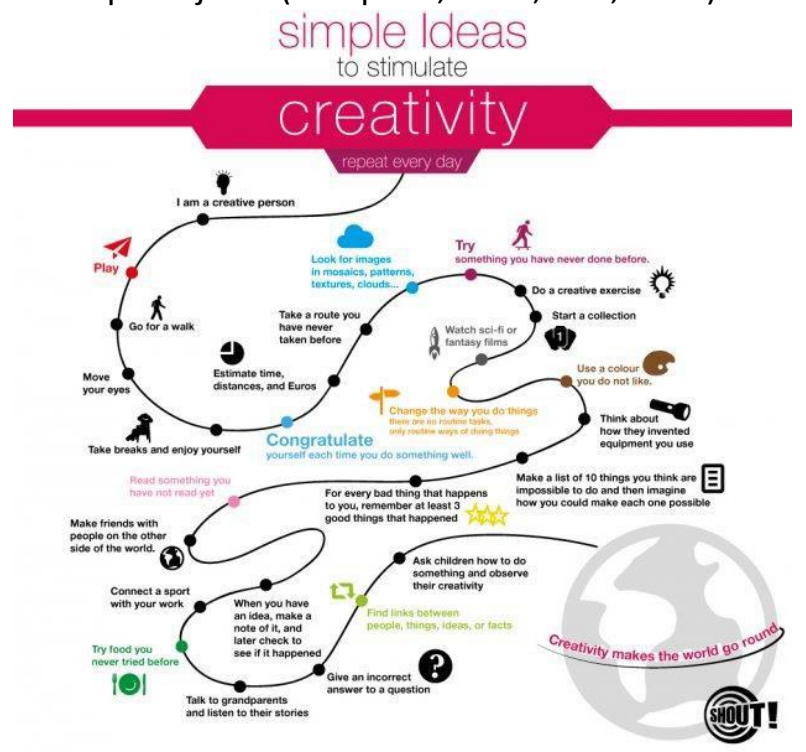

Gambar 1. Ideas to Stimulate Your Creativity Sumber: inc.com, 2015

\section{METODE}

Penelitian dimulai pada tanggal 21 Januari 2020 hingga 11 maret 2020. Penelitian ini dilakukan pada Kelurahan Pegadungan, khususnya pada jalan Taman Surya 5 dan sekitar karena tapak terpilih berada pada Jl. Taman Surya 5. Kriteria pemilihan tapak berdasarkan kebutuhan, yaitu: 1) Dekat dengan beberapa sekolah, 2) Merupakan jalur yang ramai digunakan dari pagi hingga malam, dan 3) Tapak merupakan tanah kosong atau bangunan yang sudah tidak terpakai.

\section{Metode Pengumpulan Data}

Penelitian ini menggunakan metode pengumpulan data yang dibagi menjadi dua kategori yaitu:

a. Data Primer

Perolehan data dari kelurahan dan internet

Pada tahap pertama, penelitian dilakukan dengan mengumpulkan data-data Kelurahan Pegadungan dari kantor kelurahan, namun hanya mendapatkan data jumlah penduduk berdasarkan usia. Sehingga perolehan data kawasan dilakukan dengan menggunakan media internet. Data yang didapatkan adalah jumlah sekolah, jumlah siswa berdasarkan tingkatan (SD, SMP dan SMA/SMK). Namun data yang didapatkan merupakan data seKecamatan bukan Kelurahan.
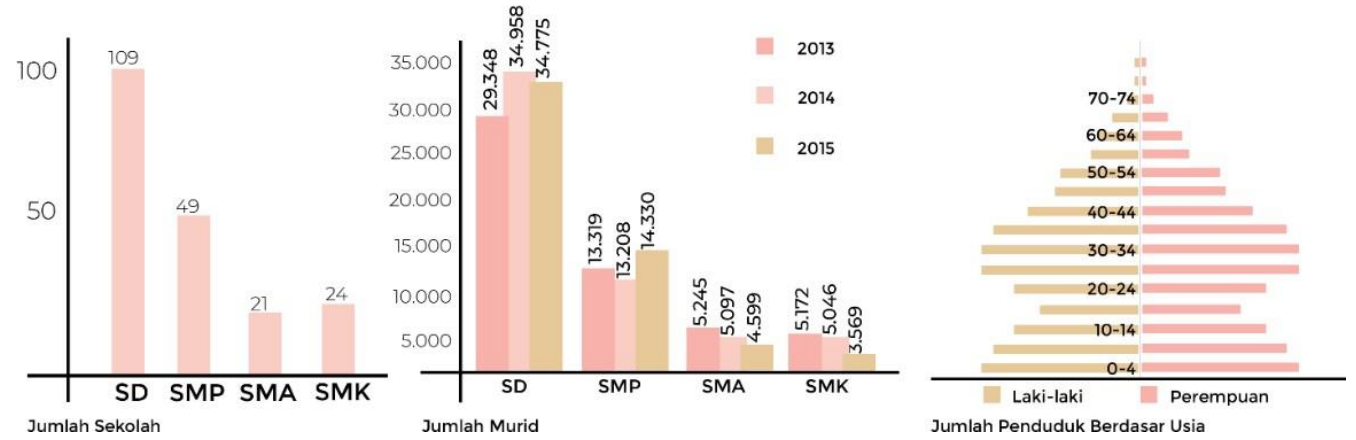

Gambar 2. Data Jumlah Penduduk Sumber: BPS Kota Adm_Jakarta Barat, 2015 


\section{Observasi}

Karena kurangnya data tertulis mengenai Kelurahan Pegadungan, maka penelitian dilanjutkan dengan tahap dua yaitu metode observasi. Metode observasi ini dilakukan pada tiga waktu yaitu pagi (07.00-09.00), siang (13.00-15.30) dan malam (18.00-20.00), dimana hal ini dilakukan untuk mengetahui kondisi tapak, titik-titik keramaian, fasilitas publik yang ada pada Kelurahan Pegadungan dan aktivitas yang sering dilakukan pada kawasan ini. Sehingga dapatlah isu pertama yang dapat diangkat berdasarkan penelitian tahap satu dan dua yaitu tidak terdapatnya wadah aktivitas sepulang sekolah.

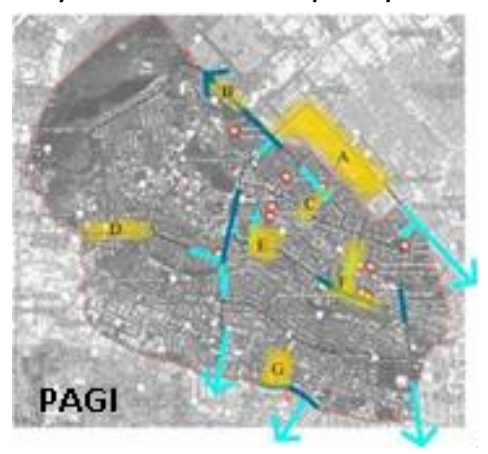

Gambar 3. Titik Keramaian Kelurahan Pegadungan

Sumber: Gambar Pribadi, 2020

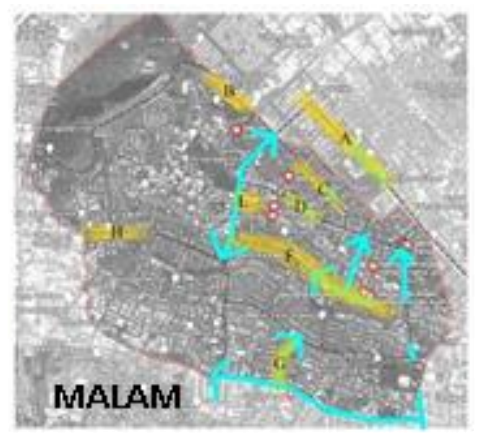

MALAM

\section{Kuisioner}

Pada tahap ketiga, dilakukan metode kuisioner untuk mengetahui permasalahan lebih lanjut dan apa yang diinginkan oleh masyarakat Pegadungan. Kuisioner dibagikan kepada masyarakat dengan usia 15-50 tahun dengan menggunakan google form yang disebarkan melalui sosial media ke beberapa sekolah dan lingkungan sekitar. Untuk tidak terjadi kesalahan pemahaman dalam pertanyaan, beberapa pertanyaan diberi pilihan jawaban. Lalu penulis juga membutuhkan pandangan atau komentar responden tentang pemikiran mereka sendiri terhadap pertanyaan yang ditanyakan maka diberikan kolom penjelasan di setiap pertanyaannya. Hal ini bertujuan agar penulis mengetahui seberapa pahamnya responden terhadap pertanyaan agar tidak terjadi respon yang tidak valid.

\section{b. Data Sekunder}

Studi Literatur

Studi literatur dilakukan setelah mengetahui isu kawasan yaitu mengenai kurangnya wadah aktivitas sepulang sekolah dan wadah interaksi masyarakat. Sehingga terdapat teori-teori tentang kawasan, interaksi masyarakat dengan kawasan dan interaksi sesama masyarakat. Studi ini dicari melalui buku, web, berita maupun jurnal.

Studi Kasus

Setelah mengetahui isu kawasan dan teori-teori pendukung, studi kasus digunakan untuk melihat kasus-kasus serupa yang menggunakan teori serupa. Tujuannya adalah untuk mengetahui apakah teori-teori tersebut dapat digunakan dan mengetahui tipologi-tipologi ruang yang sesuai dengan permasalahan. Beberapa dari studi kasus tersebut adalah: 1) $M$ Bloc Space, 2) Sarugaku Shopping Center, dan 3) ESoA School of Art.

\section{DISKUSI DAN HASIL}

Ide awal penelitian ini adalah untuk mengetahui kebutuhan dan kekurangan pada kawasan Pegadungan. Setelah mengetahui data dan observasi pada kawasan ini, didapati beberapa permasalahan dimana tidak adanya fasilitas publik yang dapat mendukung kebutuhan masyarakat Pegadungan. Oleh karena itu dilakukan penelitian lebih lanjut mengenai permasalahan kawasan. 


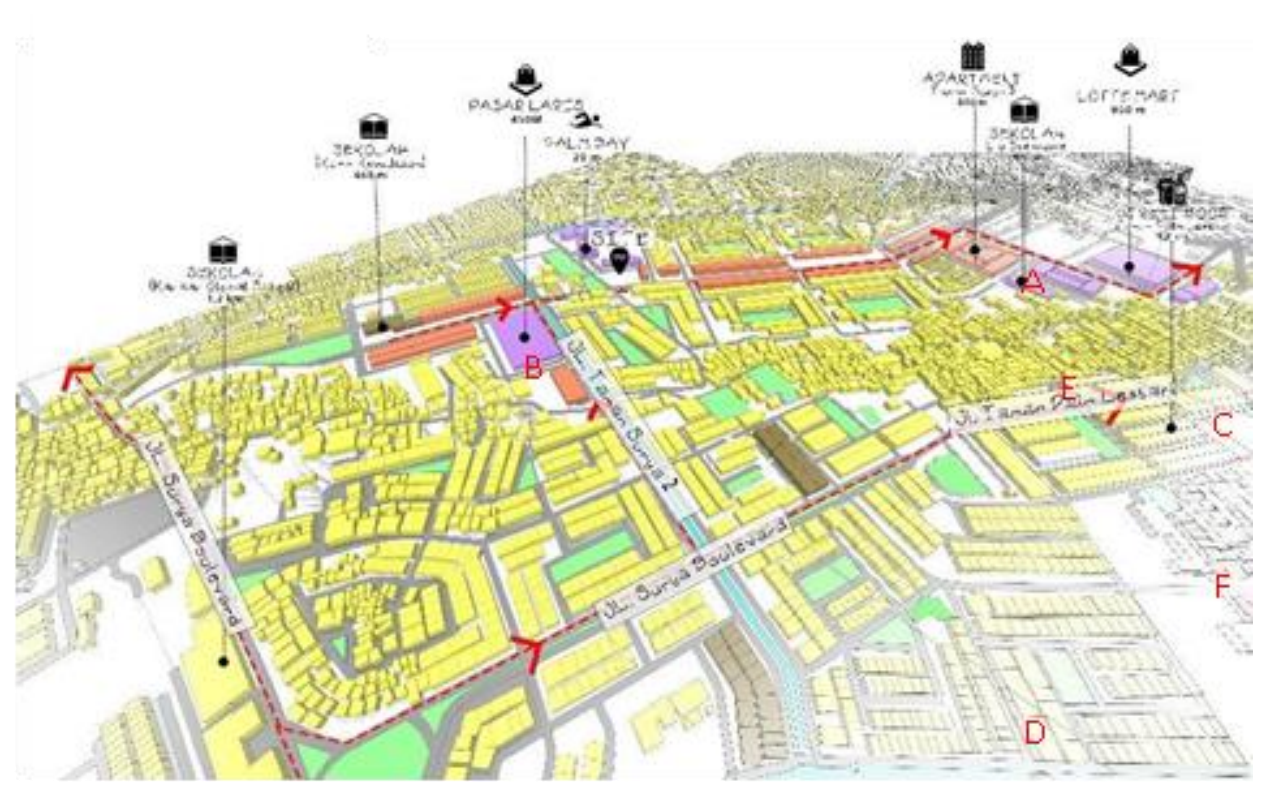

Gambar 4. Zoning Kawasan

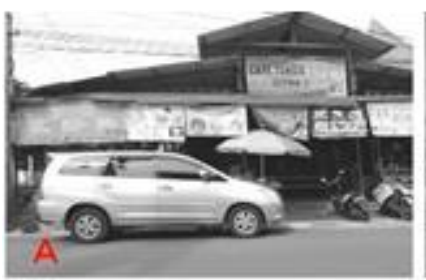

Sumber: Gambar Pribadi, 2020
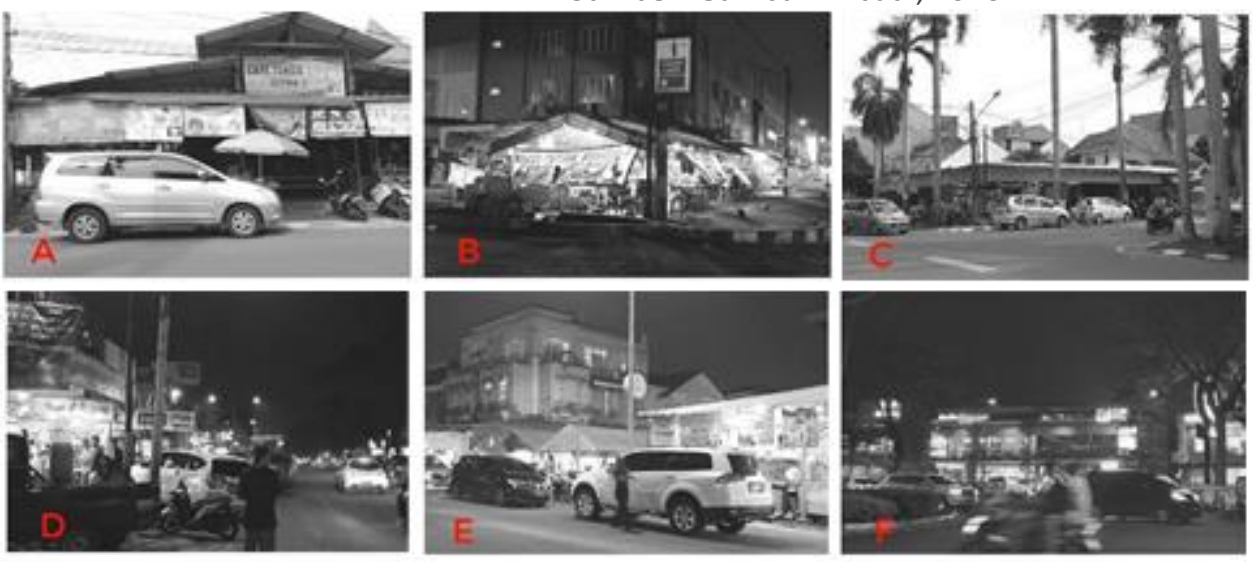

Gambar 5. Titik Keramaian

Sumber: Foto Pribadi, 2020

Hasil dari observasi adalah, terdapat titik-titik keramaian yang merupakan tenda atau ruko makanan (pada pagi hingga malam hari), sarana olah raga (pagi dan sore hari), pasar (pada pagi hingga siang hari) dan tempat lainnya yang dapat dilihat pada diagram berikut:

\begin{tabular}{|c|c|c|c|}
\hline BEROLAHRAGA & 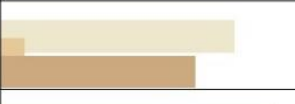 & 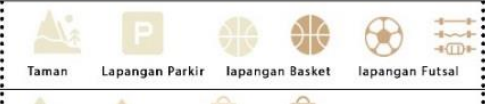 & iำ \\
\hline BELANJA & 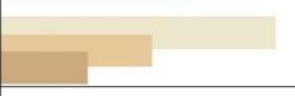 & 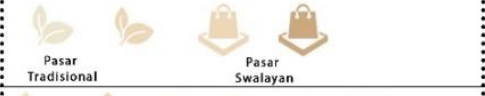 & 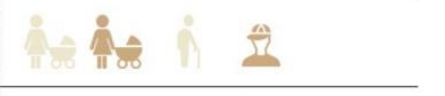 \\
\hline NONGKRONG & 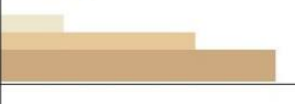 & 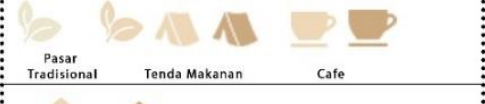 & 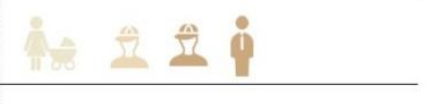 \\
\hline NGELES & H & 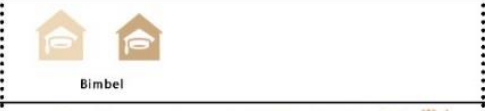 & $\therefore+\frac{A}{B}$ \\
\hline MAKAN & $y_{1}$ & \begin{tabular}{l}
$\substack{\text { Pasar } \\
\text { Tradisional }}$ \\
\hdashline
\end{tabular} & ํㅡㄹำ \\
\hline AKTIVITAS & FREKUENSI & TEMPAT & PENGGUNA \\
\hline
\end{tabular}

Gambar 6. Aktivitas Kawasan

Sumber: Gambar Pribadi, 2020 


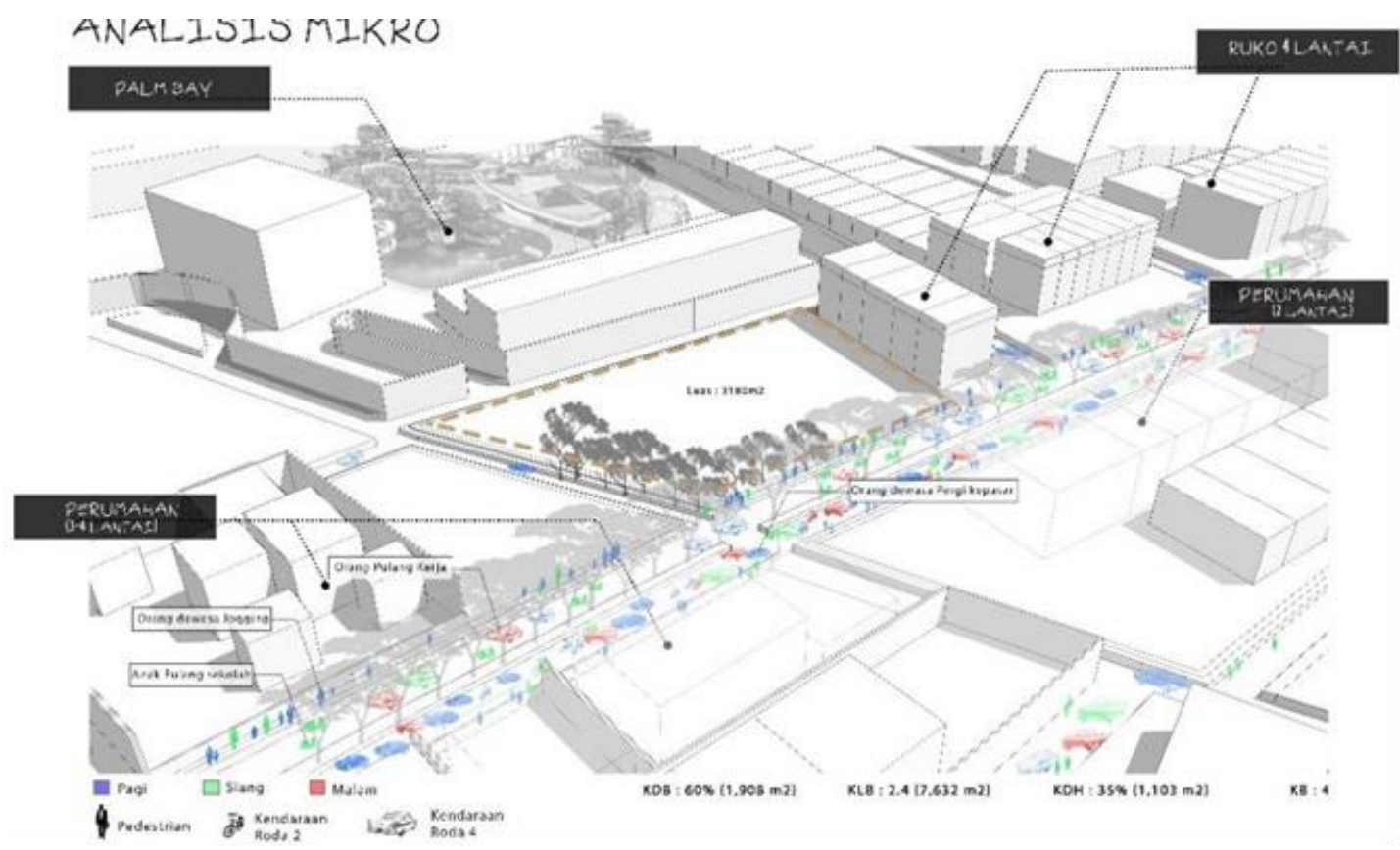

Gambar 7. Aktivitas Sekitar Tapak

Sumber: Gambar Pribadi, 2020

Setelah dilakukan observasi, diketahui bahwa Kelurahan Pegadungan membutuhkan ruang publik yang dapat mewadahi: 1) Interaksi dengan sesama, 2) Aktivitas yang dilakukan sepulang sekolah, 3) Pendalaman minat bakat. Maka langkah berikutnya adalah mengetahui lebih spesifik program aktivitas untuk kebutuhan masyarakat Pegadungan. Lalu setelah mengetahui konteks kawasan Pegadungan dan aktivitas yang sering dilakukan pada kawasan ini, langkah berikutnya mengkerucutkan pertanyaan untuk kuisioner ke arah aktivitas apa yang sering dilakukan. Berikut merupakan daftar pertanyaan kuisioner yang akan disebar melalui google form: 1) Jika ada waktu kosong, aktivitas apa yang sering anda lakukan di lingkungan perumahan mu? 2) Apa yang yang sering anda lakukan sebelum atau sesudah rutinitas anda? 3) Tempat mana yang akan anda datangi jika anda sedang bosan atau stress dengan kesibukan sehari" anda? 4) Apakah hal yang mempengaruhi anda untuk terus datang ke suatu tempat di daerah perumahan atau tempat rutinitas mu? 5) Menurut anda apakah pemfokusan pembelajaran untuk apa yang akan anda tekuni kedepannya itu penting? 6) Jika ada tempat untuk pemfokusan pembelajaran anda diluar sekolah bidang apa yang ingin anda tekuni atau pelajari? 7) Menurut anda dengan mempelajari bidang yang anda sukai apakah dapat mengurangi tingkat stress anda? Kuisioner ini dibagikan pada tanggal 9 Februari 2020 hingga 17 Februari 2020. Kuisioner ini mendapatkan responden sejumlah 120 orang yang terdiri darikategori usia 58.3\% 18-29 tahun, 21.7\% 30-50 tahun, 15.8\% diatas 50 tahun dan 4.2\% 10-17 tahun. Dan berikut merupakan hasil dari kuisioner: 


\section{HASIL KUISIONER}

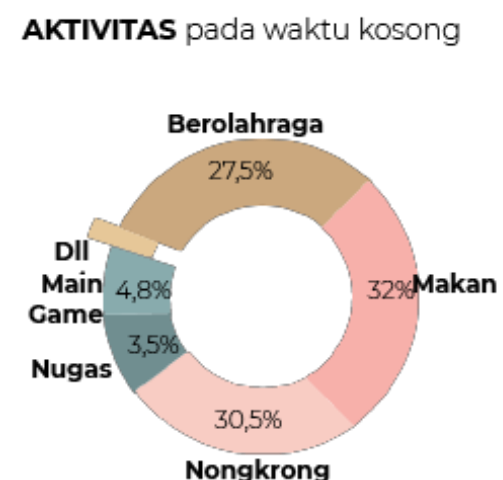

TEMPAT yang sering di datangi

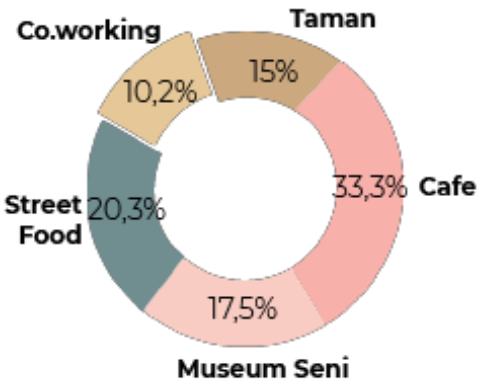

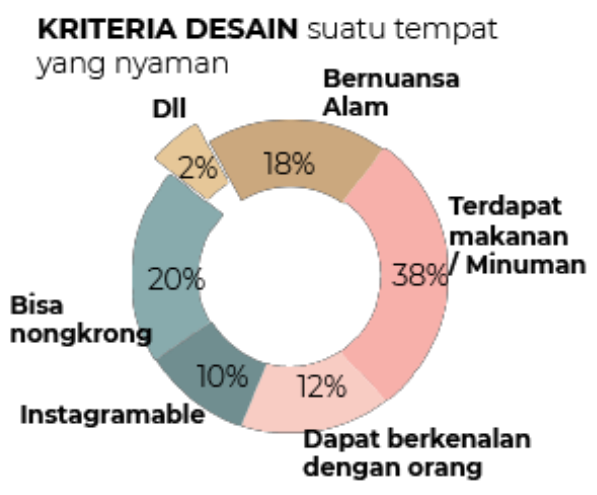

BIDANG yang ingin di pelajari

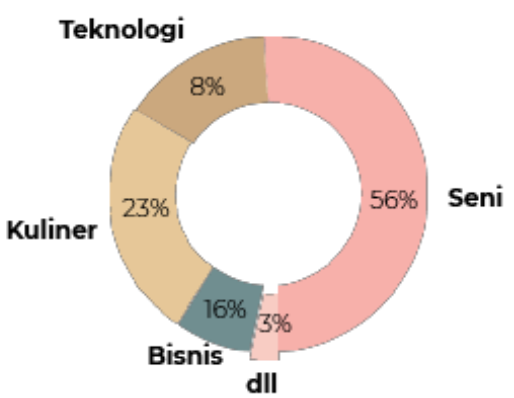

Gambar 8. Hasil Kuisioner

Sumber: Gambar Pribadi, 2020

Kesimpulan dari kuisioner ini mendapati orang-orang pada kawasan ini paling banyak melakukan aktivitas olahraga, nongkrong dan makan, dimana hal ini dibuktikan dengan hasil observasi dimana titik-titik keramaian merupakan tempat nongkrong, streetfood dan tempat berolahraga seperti tempat jogging dan lapangan basket. Adapun daya tarik orang-orang terhadap suatu tempat adalah dapat dengan bebas duduk dan bersantai tanpa dibatasi apapun, bernuansa alam dan terdapat aspek pendukung lainnya seperti dapat makan, minum dan tempat memiliki konsep yang bagus dan kekinian. Lalu menyangkut isu tentang pendalaman bakat, hal yang ingin dipelajari paling banyak merupakan seni (music, melukis dan lainnya). Responden juga menyetujui bahwa tempat dengan deskripsi diatas dapat mengurangi tingkat stress seseorang dan mendukung bila terdapat tempat tersebut di kawasan ini. Sehingga diketahui bahwa Kelurahan Pegadungan ini membutuhkan fasilitas publik yang terdapat aktivitas seperti 1) pendalaman bakat bidang seni, 2) pelatihan UKM, 3) tempan makan dan bersantai, dan 4) tempat untuk belajar bersama. Penambahan konsep Third place pada fasilitas publik dengan aktivitas pengembangan bakat bidang seni ini sangatlah dibutuhkan. Terutama, banyaknya penduduk dengan usia produktif dan orang-orang yang bekerja sehingga konsep third Place ini dapat menjadi daya tarik dan kenyamanan bagi orangorang tersebut. Fasilitas publik ini harus netral dan reguler sehingga semua orang bisa masuk dan merasa tidak asing dengan aktivitas yang ada. Namun pada kawasan Pegadungan sudah terdapat tempat makan, olahraga dan tempat untuk bersantai sehingga aktivitas-aktivitas tersebut dapat menjadi tempat reguler bagi orang-orangg dan menjadi daya tarik untuk datang ke fasilitas publikini. 


\section{KESIMPULAN DAN SARAN}

Kelurahan Pegadungan merupakan kawasan dengan zonasi perumahan yang memiliki fasilitas edukasi yang banyak namun belum adanya fasilitas edukasi yang fokus pada pendalaman minat dan bakat dalam satu bidang. Padahal, pendidikan kedepannya akan berfokus pada beberapa bidang tertentu agar murid-murid dapat menentukan minatnya sejak usia produktifnya. Pada beberapa teori dan studi kasus yang sudah di bahas sebelumnya juga dapat membuktikan bahwa pendalaman minat dan bakat anak usia produktif dapat memperluas wawasan dan meningkatkan produktivitas belajar. Terutama pada bidang seni visual dimana Masyarakat Pegadungan kebanyakan suka dan ingin mempelajari lebih lagi seni visual. Lalu untuk menjadikan aktivitas pengembangan bakat ini dapat diterima oleh penduduk sekitar, perlu di tambahkan konsep third place pada bangunan. Konsep third place ini dimasukan kedalam bangunan agar bangunan tersebut dapat menjadi fasilitas publik yang netral dan reguler sehingga semua orang dengan segala kalangan usia dapat datang dan merasa tidak asing lagi pada tempat tersebut. Oleh karena itu perlu ditambahkan aktivitas yang sudah biasa dilakukan oleh penduduk sekitar seperti taman bermain dan olahraga, kuliner dan tempat bermain. Sehingga Kelurahan Pegadungan membutuhkan adanya fasilitas publik dimana didalamnya terdapat aktivitas pendalaman bakat pada suatu bidang tertentu seperti seni visual. Dengan adanya penelitian ini, diharapkan penerapan konsep pendalaman minat dan bakat dapat diterapkan dan lebih diperhatikan lagi pada bangunan publik atau sekolah. Lalu penerapan bangunan publik ini dapat di gabungkan dengan konsep "third place" sehingga dapat mendatangkan pengunjung ke bangunan tersebut.

\section{REFERENSI}

BPS Kota Administrasi Jakarta Barat. (2015). Jakarta Barat dalam Angka 2015. BPS Kota Administrasi Jakarta Barat.

Campbell, D. (2017). Mengembangkan kreativitas diterjemahkan oleh A. M. Mangunhardjana. Yogyakarta: PT. Kanisius.

Firdaus, Y. \& Anindyaputri, I. (2017). Kinerja Otak Manusia Akan Memuncak di Usia Berapa, Sih?, diunduh 11 Juli, 2020, from https://hellosehat.com/hidup- sehat/fakta-unik/puncakkinerja-otak-manusia/

Florida, R. L. (2014). The rise of the creative class. New York: Paperback.

Hadijah, S., (2018), Memilih Sistem Pendidikan yang Tepa untuk Anak, diunduh 11 Juli, 2020, from https://www.cermati.com/artikel/memilih-sistem-pendidikan-yang-tepat-untukanak

Halodoc, R. (2020). Sekolah internasional dengan kurikulum IB banyak sekali diminati. Ketahui lebih lanjut tentang kurikulum IB, diunduh 11 Juli, 2020, from https://www.halodoc.com/artikel/pilih-sekolah-internasional-ini-yang-dimaksudkurikulum-ib

Kim, L. (2015). 9 Ways to Dramatically Improve Your Creativity. Retrieved July 11, 2020, from https://www.inc.com/larry-kim/9-ways-to-dramatically-improve-your-creativity.html

Montgomery, C.(2013). Happy City: transformingour lives trougn urban design. First Edition. New York: Farrar, Straus and Giroux.

Oldenburg, R. (1997). The great good place: Cambridge. Philadelphia: Da Capo Press.

Supplemental Material for Differentiation of Cognitive Abilities Across the Life Span. (2009). Developmental Psychology. doi:10.1037/a0015864.supp 